\title{
Potensi Legum Pohon "Dema" Asal Kabupaten Sarmi Papua Sebagai Hijauan Pakan
}

\section{The Potential of Dema Tree Legume in Sarmi Papua as a Forage}

\section{Diana Sawen ${ }^{1)^{*}}$, Luki Abdullah ${ }^{2)}$}

${ }^{1}$ Sublab Agrostologi, Fakultas Peternakan Universitas Papua, Manokwari; Jl. Gunung Salju, Amban, Manokwari 98314, Papua Barat. Indonesia

${ }^{2)}$ Departemen Ilmu Nutrisi dan Pakan, Fakultas Peternakan IPB Bogor Jl. Agathis Kampus IPB Dramaga Bogor 16680 Jawa Barat. Indonesia

Article history

Received: Mar 2, 2020;

Accepted: Aug 15, 2020

* Corresponding author:

E-mail:

sawendian@yahoo.com

DOI:

10.46549/jipvet.v10i2.99

\section{Abstract}

A preliminary study was carried out to determine the potential of dema tree legumes from Sarmi Papua as forage. Dema is the name of the local language for this legume. This study was conducted for 10 months in Sarmi regency, using a case study method with survey techniques, interviews, and laboratory analysis. The observations made included identification of species, morphology, and habitat as well as nutrient content. The results of this study indicate that there are two species of dema legume, the morphology was different in habitat description and leaf morphology. Propagations are by stem cuttings and seeds. The legumes nutritional content are $18.87 \%$ crude protein, $16.18 \%$ crude fiber, $3.97 \%$ calcium, and 17 amino acids. Forage production is around $2-4 \mathrm{~kg} /$ tree/3 months. Species identified as Ormocarpum orientale. The conclusion is dema legume has potential as forages.

Keywords : Forages; Legumes; Potency; Sarmi

\section{Abstrak}

Suatu studi awal telah dilakukan untuk mengetahui potensi leguminosa pohon "dema" asal Kabupaten Sarmi Propinsi Papua sebagai hijauan pakan. Dema merupakan nama dari bahasa lokal untuk menyebut legume ini. Studi dilakukan selama 10 bulan, bertempat di kabupaten Sarmi, menggunakan metode studi kasus dengan teknik survei, wawancara dan analisis laboratorium. Pengamatan yang dilakukan meliputi identifikasi spesies, morfologi dan habitat serta kandungan gizi. Hasil studi menunjukkan bahwa terdapat 2 spesies legume dema, morfologinya spesifik pada deskripsi habitat dan morfologi daun. Perkembangbiaknnya dengan stek batang dan biji. Selanjutnya legume dema memiliki kandungan protein kasar sebesar 18,87\%, serat kasar 16,18\%, Kalsium (Ca) 3,97\% dan juga 17 asam amino. Produksi hijauannya, 2-4 kg/pohon/3 bulan dan spesies teridentifikasi dengan nama Ormocarpum orientale. Dengan demikian berpotensi sebagai hijauan pakan.

Kata kunci: Hijauan pakan; Legume pohon; Potensi; Sarmi 


\section{PENDAHULUAN}

Berdasarkan klasifikasinya, tumbuhan pakan terdiri dari jenis rumput-rumputan (Graminae) dan legum (leguminosae). Jenis Graminae merupakan sumber serat kasar yang membentuk energi, sedangkan leguminosa merupakan sumber protein karena umumnya mengandung protein kasar $>18 \%$. Semua tumbuhan pakan telah ada atau disediakan alam dengan semua potensinya masing-masing untuk dapat dimanfaatkan secara optimal bagi kelangsungan hidup ternak terutama ternak ruminansia sesuai dengan kebutuhan nutrisinya. Terjaminnya suplai kebutuhan nutrisi bagi ternak ruminansia menjadi mutlak diperlukan bagi kelangsungan hidup dan produktivitas ternak dan sudah tentu memerlukan kesinambungan produksi hijauan pakan yang berkualitas tanpa mempertimbangkan musim atau iklim.

Kontinuitas suplai hijauan pakan pada musim kemarau di beberapa daerah beriklim kering di Indonesia, dapat bertahan dengan adanya budidaya tanaman leguminosa pohon seperti gamal, lamtoro, kaliandra, indigofera, desmodium dan flemingia (Suherman dan Herdiawan, 2015) sebagaimana yang sudah dilakukan di daerah NTT dan NTB. Budidaya legum pohon, sudah sejak lama dilakukan oleh para petani dan peternak di lahan-lahan kritis ataupun lahan kering, terutama yang berdekatan dengan areal hutan maupun perkebunan ataupun lahan-lahan pertanian, sebenarnya secara realita merupakan bagian dari tujuan lain pengembangan budidaya hijauan pakan. Tujuan tersebut antara lain: sebagai pagar hidup, sebagai tanaman konservasi, sebagai bahan bakar, sebagai tanaman pelindung, sebagai pencegah erosi dan lain-lain.

Tanaman legum dibudidayakan sebagai tanaman konservasi dalam upaya untuk mempertahankan tingkat kesuburan tanah karena dapat digunakan juga sebagai pupuk hijau. Setiap jenis leguminosa tentunya memiliki potensi yang berbeda ketika dibudidayakan pada daerah yang berbeda sesuai dengan kondisi lahan yang tersedia. Bahkan saat ini, jenis Indigifera zollingeriana merupakan legum pohon potensial yang sudah dan sementara dikembangkan di Indonesia sebagai industri konsentrat hijau yang memiliki prospek menjanjikan dan telah dibuktikan di daerah Jawa Barat, Lampung dan Jawa Timur dengan hadirnya pabrik atau industri penghasil pellet indigofera sebagai pakan hijauan dan sekaligus bisa sebagai pengganti konsentrat.

Papua memiliki potensi sumber daya hijauan pakan potensial di setiap daerahnya, yang perlu dikaji lebih awal melalui eksplorasi untuk tujuan pembudidayaan dan pengembangan lebih lanjut, selain potensi padang rumput alam, yang juga merupakan salah satu sumber pakan hijauan (Junaidi dan Sawen, 2010). Kajian riset sebelumnya tentang rumput Kebar (Biophytum petersianum Klotszch) dapat dimanfaatkan sebagai hijauan pakan dan secara langsung dimanfaatkan oleh ternak sapi Bali, babi dan ayam kampung di Kebar Kabupaten Tambrauw (Sawen, 2011; Sawen, 2012).

Kabupaten Sarmi merupakan pemekaran dari kabupaten Jayapura tahun 2002 dengan luas wilayah $17.740 \mathrm{~km}^{2}$ dengan jumlah penduduk 36.797 jiwa dan terdiri dari 19 distrik, 112 kampung dan 3 kelurahan (Bappeda Kab. Sarmi, 2018). Daerah ini memiliki potensi padang rumput alam dan sumberdaya pakan yang potensial untuk dikembangkan sebagai hijauan pakan guna menunjang usaha-usaha peternakan ruminansia yang selama ini sudah dibudidayakan oleh masyarakat petani peternak yang ada. Jumlah populasi ternak sapi dari tahun ke tahun terus mengalami peningkatan, dimana tahun 2017 adalah 5132 ekor dan tahun 2018 menjadi 5350 dan data terbaru sampai dengan Juni 2019 adalah 5781 ekor, atau dengan kata lain setiap tahun meningkat sekitar $3 \%$. Sedangkan ternak kambing saat ini berjumlah 501 ekor dan ternak babi dengan populasi 4215 tahun 2018 menjadi 4251 ekor di tahun berjalan (Dinas Pertanian Kabupaten Sarmi, 2019).

Legum pohon dema merupakan salah satu legume yang baru ditemukan di Sarmi, sebagai hijauan pakan yang perlu dikaji lebih lanjut guna pengembangannya sebagai salah satu aset dan income daerah ke depannya. Dema merupakan nama lokal dari bahasa daerah masyarakat Sarmi untuk menyebut legum pohon ini. Realitanya, legum ini juga dikonsumsi oleh manusia sebagai sumber vitamin terutama bagian yang muda termasuk 
pucuk daun, seperti pada kelor dan katuk, sedangkan bagian yang tua diberikan juga kepada ternak kambing kacang dan sapi Bali yang dipelihara oleh masyarakat (hasil observasi lapangan). Potensi lainnya, legum pohon ini tumbuh secara alami dan berlimpah di alam, mulai dari daerah pesisir pantai sampai ke arah pegunungan (sekitar $>350 \mathrm{~m} \mathrm{dpl}$ ). Menariknya lagi bahwa ternak yang mengkonsumsi legum ini memberikan performans yang baik dari segi pertumbuhan juga produksinya. Berdasarkan uraian di atas, perlu dilakukan kajian lebih lanjut untuk mengetahui kandungan gizinya dan potensi leguminosa pohon dema asal Kabupaten Sarmi Papua sebagai sumber pakan hijauan. Penelitian ini bertujuan untuk mengetahui potensi leguminosa pohon dema asal Kabupaten Sarmi Papua sebagai sumber pakan hijauan.

\section{MATERI DAN METODE}

\section{TEMPAT DAN WAKTU}

Penelitian dilakukan di 15 lokasi kampung di Kabupaten Sarmi selama 2 bulan (JuniAgustus) tahun 2019. Analisis bahan kering dilakukan di Sub Lab. Agrostologi Fapet UNIPA Manokwari, analisis proksimat dan asam amino dilakukan di Laboratorium Ilmu dan Teknologi Peternakan Fapet IPB Bogor, dan analisis mineral lengkap dilakukan di Lab. Analisis Proksimat BPT Ciawi Bogor. Khusus untuk identifikasi spesies legume dilakukan di Pusat Penelitian Biologi Tumbuhan LIPI, Cibinong Bogor dan dilanjutkan ke Royal Botanic Garden Kew, UK.

\section{BAHAN DAN PERALATAN}

Bahan yang digunakan dalam penelitian ini antara lain, alkohol $70 \%$ untuk pembuatan specimen, dan sampel legume dema. Sedangkan alat yang digunakan terdiri dari kertas koran bekas, kapas, label, penjepit specimen, gunting stek, penggaris, camera, GPS, plastik sampel, peralatan untuk analisis bahan kering (oven, desikator, timbangan digital, alumunium foil, baki sampel, gegep, dan blender).

\section{METODE}

Penelitian menggunakan metode studi kasus dengan teknik survei dan wawancara, juga dilakukan analisis laboratorium (proksimat, asam amino dan mineral) dan identifikasi spesies serta uji agronomis untuk budidaya legum dema.

\section{PROSEDUR PELAKSANAAN}

Penelitian diawali dengan melakukan pendekatan melalui wawancara dengan key informan (orang tua-tua) yang ada di kampung tentang asal usul spesies legume tersebut dan juga wawancara dengan masyarakat yang memanfaatkannya. Kemudian melakukan survey dengan melakukan observasi pada kebun-kebun, pinggiran hutan, pinggiran sungai dan pekarangan di sekitar pemukiman warga untuk mengetahui habitat dan morfologi secara visual. Selanjutnya dilakukan pembuatan specimen secara lengkap (daun, bunga, dan buah) dan juga mengumpulkan sampel dari bagian daun dan batang untuk keperluan analisis laboratorium. Khusus untuk uji agronomisnya dilakukan dengan mengumpulkan biji dari buah yang ditemukan di lapangan dan ditanam atau dibudidayakan.

\section{HASIL DAN PEMBAHASAN}

\section{KONDISI UMUM KABUPATEN SARMI}

Kabupaten Sarmi terletak di bagian utara Provinsi Papua atau pulau Papua pada $1^{0} 35^{\prime}$ dan $3^{0} 35^{\prime}$ Lintang Selatan dan $138^{\circ} 05^{\prime}$ dan $140^{0} 30^{\prime}$ Bujur Timur. Batas administrasi Kabupaten Sarmi, antara lain: sebelah utara berbatasan dengan Samudera Pasifik, sebelah selatan berbatasan dengan Kabupaten Mamberamo Tengah, sebelah timur berbatasan dengan Kabupaten Jayapura dan sebelah barat berbatasan dengan Kabupaten Mamberamo Raya.

Jenis tanah dan kondisi peruntukkannya di Kabupaten Sarmi antara lain: Entisol (untuk pengembangan pertanian, yaitu di daerah Pantai Timur dan Pantai Timur Barat; inseptisol sebagai penyangga cadangan air tersebar di wilayah kabupaten Sarmi, ultisol sebagai representasi kandungan besi $(\mathrm{Fe})$ yang tinggi; alfisol sebagai wilayah pengembangan pertanian dan peternakan, terutama di daerah Sarmi, Sarmi Timur, Pantai Barat, Pantai Timur, Apawer Hulu dan Tor Atas; Oxisol dan mollisol, keduanya untuk penggembalaan 
ternak dan pengembangan pertanian (Bappeda Kab. Sarmi, 2018).

\section{KONDISI USAHA PETERNAKAN RAKYAT}

Kebanyakan masyarakat petani peternak di Kabupaten Sarmi, melakukan usaha peternakan sebagai usaha sambilan dengan skala usaha yang kecil dan sistem pemeliharaan yang masih tradisional, ternak dibiarkan berkeliaran untuk mencari pakan sendiri. Khusus untuk ternak sapi Bali dan kambing, ada beberapa peternak yang sudah mulai berkembang ke sistem pemeliharaan semi intensif dengan menyediakan kandang ataupun menggembalakan ternaknya pada areal atau lokasi yang banyak hijauan pakan. Peternak di daerah pemukiman transmigrasi di Distrik Bonggo, usaha peternakannya sudah banyak berkembang dengan sistem pemeliharaan semi intensif yang pakan hijauan juga disiapkan oleh peternak dengan pola "cut and carry" pada kebun rumput maupun hijauan pakan yang tumbuh alami di alam. Masyarakat umumnya memiliki mata pencaharian utama sebagai petani dan nelayan.

Sumber daya lainnya yang potensial antara lain adanya beberapa padang rumput alam dan padang penggembalaan, yang luasannya belum terukur secara kuantitatif. Selain ruminansia, ada ternak babi, unggas yaitu ayam kampung dan bebek, serta ada juga rusa yang dipelihara. Adanya program pemerintah pusat berupa Otonomi Khusus (Otsus) Papua, Program
Nasional Pemberdayaan Masyarakat (PNPM) Mandiri Perdesaan sebelumnya dan Dana Desa, turut memberikan kontribusi positif bagi masyarakat karena setiap kepala keluarga (KK) atau petani peternak maupun kelompok wajib menerima dan mengelola bantuan termasuk ternak sapi Bali, ternak babi dan saprodi (sarana prasarana produksi) di kampungnya. Pembinaan biasanya dilakukan oleh pendamping atau penyuluh dan juga dari instansi terkait.

\section{HASIL IDENTIFIKASI SPESIES DAN MORFOLOGI}

Legum dema yang ditemukan di lapangan ada 2 spesies yaitu dema 01 dan dema 02 , yang secara visual dibedakan berdasarkan morfologinya (Gambar 1 dan Tabel 1), yaitu dari daun dan bunga (warna bunganya). Hasil identifikasi LIPI, sampai saat ini belum ada, dengan demikian taksonomi secara detail tidak dikemukakan. Berdasarkan hasil identifikasi Royal Botanic Garden Kew, UK pada akhir Januari 2020, kedua spesies dema telah teridentifikasi dengan satu nama yaitu Ormocarpum orientale. Sinonim spesiesnya adalah Ormocarpum sennoides dan $O$. chochinchinense. Berdasarkan beberapa referensi yang ada, diperoleh bahwa legume dema termasuk dalam genus Ormocaprum dari family Fabaceae (Nagarajan and Pandian, 2018; Lavin et al., 2001; Sukasini et al., 2015).
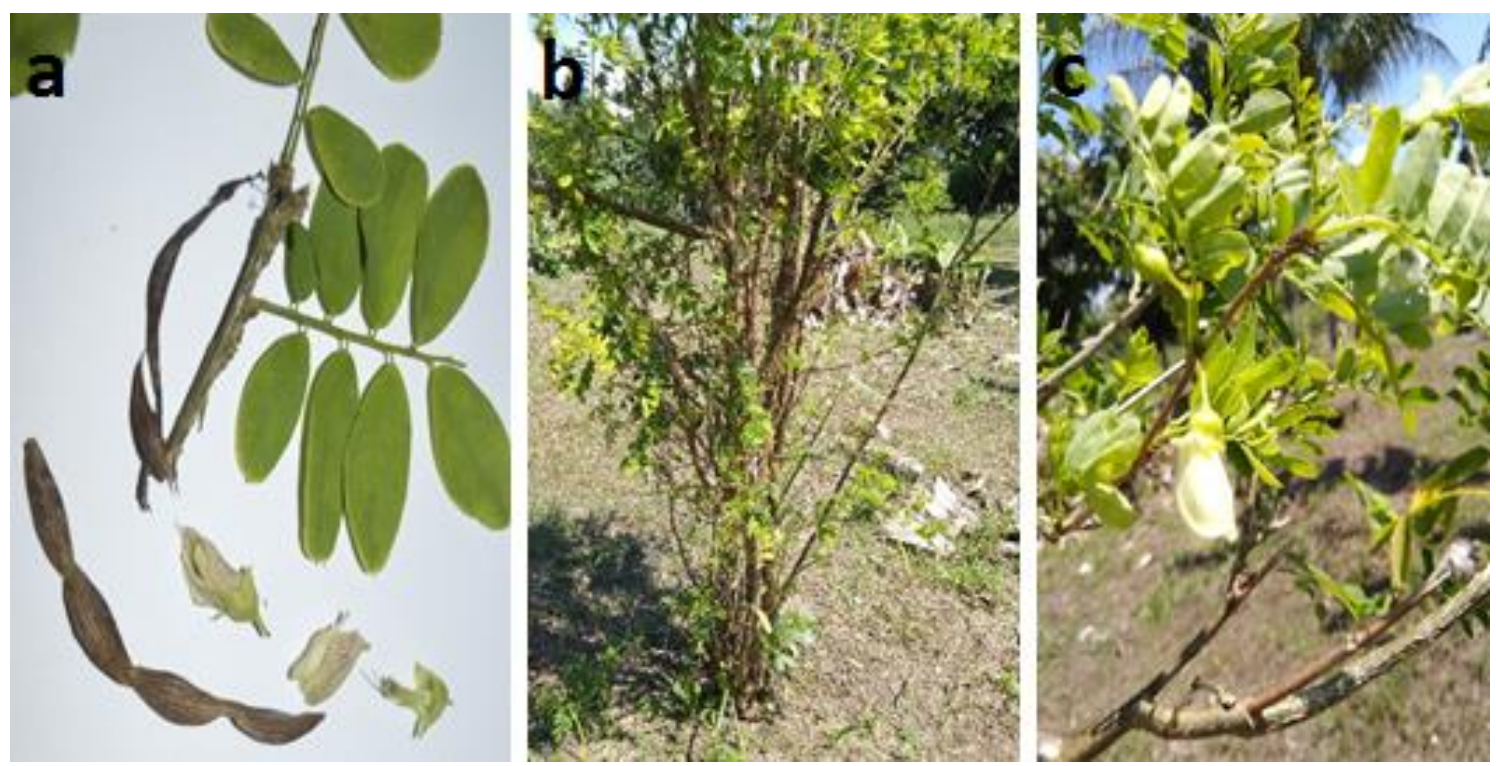

Gambar 1. Legum Dema. (a) Spesies pohon legume dema; (b) spesies dema 01; (c) spesies dema 02 
Tabel 1. Deskripsi morfologi legume dema

\begin{tabular}{lcc}
\hline \multicolumn{1}{c}{ Morfologi } & Dema 01 & Dema 02 \\
\hline Daun: & Hijau kekuningan & Hijau \\
Warna & Lebih tebal & Biasa \\
Ketebalan & kecil & Normal \\
Ukuran & majemuk & Majemuk \\
Bentuk & ganda/berpasangan & ganda/berpasangan \\
& $3-9$ & $3-9$ \\
Jumlah daun/tangkai (pasang) & Kupu-kupu & Kupu-kupu \\
Bunga: & Putih & krem, garis merah \\
Warna & & kecoklatan, seperti bermotif \\
& $5-7$ & $5-7$ \\
Lama berbunga (hari) & Januari-Desember & Januari-Desember \\
Waktu berbunga & & \\
Buah: & Polong & Polong \\
Bentuk & $1-15$ & $1-15$ \\
Ukuran/panjang (cm) & $1-9$ & $1-9$ \\
Jumlah biji/polong (buah) & & \\
Biji: & 0,5 & 0,5 \\
Ukuran/panjang (cm) & 3 & 3 \\
Tebal (mm) & & \\
Batang: & Coklat muda & Coklat \\
Warna kulit batang & $3-10$ & $3-10$ \\
Tinggi tanaman (m) & Ulat daun & Ulat daun \\
Hama yang menyerang daun & &
\end{tabular}

Legum dema merupakan jenis semak polongan/ legume pohon, tingginya dapat mencapai 3-10 m, (di India mencapai 7,5 m) dan memiliki kulit batang coklat muda yang menunjukkan kulit lebih hijau di bawahnya. Daun berpasangan pada tangkai, dengan jumlah 3-9 pasang, tunas daun berwarna kuning muda, bunga berbentuk kupu-kupu seperti kacangkacangan pada umumnya (ILDIS, 2014; Falanruw, 2015).

Hasil penelitian ini sesuai dengan beberapa hasil penelitian di PNG, Nigeria, Madagaskar, India dan Zambia (Thulin and Razafimandimbison, 2016). Polong yang dihasilkan berukuran 1-10 cm, disambung per bagiannya yang berisi 2-10 biji, bijinya berukuran kecil sekitar $0,5 \mathrm{~cm}$ dengan tebal 3 $\mathrm{mm}$. Banyak juga riset di negara mereka yang dilakukan untuk spesies legume ini, yaitu sudah ke tingkat spesifikasi gen melalui analisis DNA (Nagarajan and Pandian, 2018; Sukasini et al., 2015; Thulin et al., 2013; Lavin et al., 2001).

\section{DESKRIPSI HABITAT}

Habitat legum pohon dema, tersebar mulai dari daerah pesisir pantai sampai ke daerah pedalaman kabupaten Sarmi, dengan ketinggian tempat 0-350 $\mathrm{m}$ dpl. Legum dema 01, kebanyakan ditemukan pada pinggiran sungai atau lokasi yang berdekatan dengan sungai. Sedangkan legume dema 02, dapat ditemukan dimana saja. Percobaan agronomis dilakukan dengan mencoba menanam dengan stek batang dan biji legume dema dan sudah berhasil. Berdasarkan morfologi tinggi tanamannya, dema termasuk jenis legum pohon dan perrenial. Berkembang biak dengan stek batang dan biji.

\section{POTENSI LEGUM DEMA SEBAGAI BAHAN} MAKANAN

Legum dema tumbuh secara alami dan sudah sejak lama dikenal oleh masyarakat pribumi Sarmi dan dikonsumsi sehari-hari sebagai sumber vitamin sama seperti kebanyakan sayuran lainnya. Masyarakat menyebut sayur dema sebagai sayur kampung, bagian yang dikonsumsi adalah bagian pucuk atau daun muda. Sayur dema menjadi sayuran khas dan wajib bagi kalangan orang tua-tua sebagai warisan turun temurun. Masyarakat biasanya mengkonsumsi sayur dema bersama dengan papeda, sagu kering dan ikan. Sayur dema juga menjadi hidangan/jamuan khas 
tradisonal bagi tamu dalam acara-acara besar pemerintahan atau keagamaan.

Cara pengolahannya seperti memasak sayur bening dan juga dimasak dengan santan. Semua usia dapat mengkonsumsinya, dan jika melihat kandungan gizinya pada Tabel 2, baik untuk tumbuh kembang anak-anak (bayi dan balita) karena mengandung kalsium untuk pembentukan tulang dan gigi serta asam glutamat yang terkandung didalamnya yaitu 2,38\% mengindikasikan bahwa sayur ini dapat membantu membentuk kecerdasan anak. Observasi lapangan menunjukkan bahwa sayur ini dijual juga oleh masyarakat di pasar-pasar tradsional/pasar kampung dan pasar sentral Mararena Sarmi.

Legume dema pada beberapa daerah di Afrika seperti di India, Kenya, Mozambique dan Madagaskar, umumnya digunakan sebagai obat untuk pengobatan fraktur tulang dan juga digunakan sebagai obat (Thulin et al., 2013: Lavin et al., 2001). Spesies legume dema yang sama terdapat di Papua New Guinea, dikenal dengan "kalava" (Falanruw, 2015).

POTENSI LEGUM DEMA SEBAGAI SUMBER PAKAN

Daun legume dema yang tua biasanya diberikan pada ternak sapi Bali dan kambing. Ataupun dapat juga dikonsumsi langsung di areal dimana digembalakan atau diikat atau di areal yang dilepas, baik di pemukiman warga, kebun maupun pinggiran sungai atau jalan. Dema memiliki potensi yang baik karena ketersediaan yang melimpah di alam, palatabel, mempunyai produksi yang baik karena tidak terpengaruh musim dan secara kualitas memiliki kandungan gizi yang baik, yaitu protein kasar 18,99\% (Dema 01) dan 18, 71\% (Dema 02) (Tabel 2). Jika dibandingkan dengan kandungan gizi legume lainnya, dema masih tergolong sebagai sumber protein (nilai PK > $18 \%$ ). Kandungan gizi jenis legum yang lainnya antara lain: gamal PK 22\%, Indigofera zollingeriana PK 25-30\%, lamtoro PK 26\%, desmodium PK 20-22\%, kelor PK 26\%, kaliandra PK 20,8\% dan turi PK 29\% (Abdullah, 2014; Suherman dan Herdiawan, 2015). Kualitas suatu bahan makanan termasuk hijauan pakan ditentukan oleh kandungan proteinnya (Lubis, 1992). Jika dibandingkan dengan legum lainnya, legum dema memiliki nilai kadar kalsium yang tinggi, yang mengindikasikan bahwa legum ini sangat baik jika dikembangkan lebih lanjut dan pemanfaatannya seperti pada katuk. Tepung daun katuk mengandung PK 23,13\%, SK $29,64 \%$, sedangkan dalam daun segar mengandung $8,32 \%$ PK, lemak $9,06 \%$ dan juga memiliki 17 asam amino (Santoso, 2018) sebagaimana legume dema.

Legum dema juga memiliki 17 asam amino antara lain: asam glutamat, asam aspartat, serin, leusin, alanin, arginin, methionin, phenilalanin, lysin, prolin, valin, sistein, isoleusin, tirosin, treonin, histidin dan glisin (Lab. IPTP Fapet IPB, 2019) ${ }^{\mathrm{b}}$. Dema juga memiliki kandungan senyawa metabolit sekunder, namun belum terukur secara kualitatif dan kuantitatif. Kandungan senyawa metabolit sekunder untuk indigofera yaitu tannin sebesar 0,027-0,1\% dan saponin 2,24-4,20\% (Abdullah, 2010). Katuk memiliki senyawa alkaloid, fenol dan flavonoid (Santoso, 2018).

Tabel 2. Perbandingan komposisi nutrisi legum dema dan legum lainnya

\begin{tabular}{lccccc}
\hline Komposisi & Dema 01* & Dema 02* & D. rensonii & Kelor $^{\mathbf{b}}$ & Indigofera $^{\mathbf{c}}$ \\
\hline Bahan kering (\%) & 89,52 & 91,43 & - & 94,01 & $88,11 \pm 2,73$ \\
Protein kasar (\%) & 18,99 & 18,75 & 19,70 & 22,7 & $29,16 \pm 1,45$ \\
Serat kasar (\%) & 15,82 & 16,53 & 34,85 & 51,66 & $14,02 \pm 2,48$ \\
Lemak kasar (\%) & 3,30 & 2,28 & 9,11 & 4,65 & $3,62 \pm 0,23$ \\
Abu (\%) & 8,00 & 9,31 & 6,77 & - & $6,14 \pm 1,45$ \\
BETN (\%) & 43,41 & 44,04 & 29,58 & - & - \\
Ca (\%) & 4,24 & 3,70 & - & $3,5-5,5$ & $1,78-2,04$ \\
P (\%) & 0,69 & 0,55 & - & 0,7 & $0,34-0,46$ \\
NaCl (\%) & 0,42 & 0,21 & - & - & - \\
Vitamin A (IU/100 mg) & - & - & - & - & 5054 \\
\hline
\end{tabular}

Sumber: *Lab. Ilmu dan Teknologi Pakan Fapet IPB, Agustus 2019; a Suherman dan Herdiawan, 2015; b Aminah, Ramdhan dan Yanis, 2015; c Abdullah, 2014;

Keterangan: D: Desmodium. 


\section{POTENSI LAIN LEGUM DEMA}

Tanaman legume juga sebagai cover crop yang dapat menyuburkan tanah karena kemampuannya meningkatkan ketersediaan $\mathrm{N}$ pada tanaman oleh bintil akar yang mengandung Rhizobium (Moulin et al., 2001). Selain sangat potensial sebagai suplemen protein untuk ternak ruminansia karena memiliki kandungan $\mathrm{N}$ yang cukup tinggi (Hutasoit, 2017). Mansur (2008) juga menyatakan bahwa dalam pembentukan bintil akar, aktivitas bakteri Rhizobium pada tanaman leguminosa memberikan cukup $\mathrm{N}$ sehingga tanaman akan mempunyai sistem perakaran yang lebih besar serta menyebar dan akhirnya akan menambah penyerapan unsur hara.

Produksi legume dema yaitu 2-4 $\mathrm{kg} /$ pohon/3bulan dan tumbuh baik juga pada genangan air, berdasarkan hasil pengamatan di lapangan. Hal ini tidak jauh berbeda dengan produksi legume pohon lainnya. Produksi hijauan dari legume lamtoro, gamal dan kaliandra yaitu 3-5 kg/pohon/3bulan dan daunnya dapat dimanfaatkan sebagai pakan hijauan (Kushartono, 2002). Selain itu, keunggulan lainnya yaitu dapat tumbuh baik pada berbagai kondisi tanah, sekalipun ditanam pada lahan-lahan yang kering. Hal ini senada dengan Abdullah (2019) yang menyatakan bahwa menggunakan spesies atau cultivar tanaman pakan yang toleran terhadap kekeringan pada pertanian lahan kering di Indonesia, merupakan salah satu komponen penting dari manajemen produksi di lahan kering. Salah satu rekomendasi spesies legume pohon untuk dikembangkan saat ini adalah Indigofera, karena memiliki beberapa keunggulan yaitu produksi biomassa tinggi, mudah dibudidayakan, mudah diperbanyak, kualitas hijauan tinggi, toleran kekeringan, menahan erosi, memperbaiki kesuburan tanah, aman dan palatabel/disukai ternak. Berdasarkan hal ini, maka dapat dinyatakan bahwa legume dema dapat dikembangkan lebih lanjut sebagai pakan ternak.

\section{KESIMPULAN}

Terdapat dua spesies legum pohon dema yang berpotensi sebagai hijauan pakan ternak, dengan rata-rata kandungan $\mathrm{PK} 18,87 \%$ dan serat kasar 16,18\%, Ca 3,97\%, dengan 17 asam amino serta palatabel atau disukai ternak. Morfologi legume dema spesifik, perkembangiakannya dengan stek batang dan biji. Produksi hijauan pakannya sebesar 2-4 $\mathrm{kg} /$ pohon$/ 3$ bulan. Spesies dema teridentifikasi dengan nama Ormocarpum orientale.

\section{UCAPAN TERIMA KASIH}

Disampaikan kepada Prof. Dr. Charlie D. Heatubun, S.Hut., M.Si., yang telah membantu dalam pengiriman specimen ke Royal Botanic Garden Kew, UK; tokoh masyarakat, tokoh adat dan para kepala kampung dan masyarakat Sobey Kabupaten Sarmi, yang telah membantu kami dalam pelaksanaan penelitian.

\section{DAFTAR PUSTAKA}

Abdullah L. 2010. Herbage production and quality of Indigofera treated by different concentration of foliar fertilizer. Media Peternakan. 33 (3): 169-175.

Abdullah L. 2014. Prospektif Agronomi dan Ekofisiologi Indigofera zollingeriana sebagai tanaman penghasil hijauan pakan berkualitas tinggi. Pastura. 3(2):79-83.

Abdullah L. 2019. Peluang Pengembangan Tanaman Pakan di Lahan Kering. Prosiding Joint Seminar Nasional HITPI ke-8 dan Seminar Nasional Peternakan ke5, 5-6 November 2019, Kupang.

Aminah S., Ramadhan T. dan Yanis M. 2015. Kandungan nutrisi dan sifat fungsional tanaman Kelor (Moringa oleifera). Bulletin Pertanian Perkotaan. 5(2):35-42.

Bappeda Kabupaten Sarmi. 2018. Data dan Indikator Kabupaten Sarmi. Bappeda, Sarmi.

Dinas Pertanian Kabupaten Sarmi. 2019. Laporan Tahunan 2018. Dinas Pertanian Kabupaten Sarmi.

Falanruw M.V. C. 2015. Trees of Yap: A Field Guide. Gen. Tech. Rep. PSW-GTR-249. Hilo, HI: U.S. Department of Agriculture, Forest Service, Pasific Southwest Research Station.

Hutasoit R., Tarigan A. dan Sirait J. Tanaman pakan leguminosa dalam sistem integrasi dengan perkebunan jeruk. Pastura. 7(1): 32-36.

ILDIS. 2014. Internatinonal Legume Database and Information Service, Family Fabaceae. 
Digital Resource at www.catalogueoflife.org/col. Species 2000: Naturalis, Leiden, the Netherlands. ISSN 2405-8858.

Junaidi M. dan Sawen D. 2010. Keragaman botanis dan kapasitas tamping Padang Penggembalaan Alami di Kabupaten Yapen. Jurnal Ilmu Peternakan dan Veteriner Tropis 5(2):92-97.

Kushartono B. 2002. Potensi leguminosa pohon sebagai sumber pakan hijauan. Temu teknis Fungsional Non Peneliti. Puslitbang Pertanian Bogor.

Lab. IPTP Fapet IPB, 2019a . Laporan hasil analisis proksimat. Fapet, IPB, Bogor. Tanggal 9 Agustus 2019.

Lab. IPTP Fapet IPB, 2019 ${ }^{\mathrm{b}}$. Laporan hasil analisis asam amino. Fapet, IPB, Bogor. Tanggal 19 Agustus 2019.

Lubis D. 1992. Ilmu Makanan Ternak. PT. Pembangunan, Jakarta.

Mansyur S. H. 2008. Pengaruh inokulasi rhizobium terhadap pembentukan bintil akar kacang tanah (Arachis hypogea) di Taman hutan raya Propinsi Bengkulu. Balitbang Mikrobiologi, Puslitbang Biologi - LIPI.

Lavin M., Pennington R.T., Klitgaard B. B., Sprent J.I., Delima H. C. and Gasson P.E. 2001. The Dalbergioid Legum (Fabaceae): Delimititation of a pantropical monophyletic clade. American Journal of Botany. 88(3):503-533.

Moulin L., Munive J., Dreyfus B. and Bolvin M. C. 2001. Nodulation of legums by members of the subclass of proteobacteri. Macmillan Magazine Ltd.

Nagarajan D. and Pandian R. 2018. Anatomical studies on association of endophytic Fungi in Ormocarpum cochinchinense and Enicostema axillare. Int. Journal Current Research in bioscience and plant Biology. 5 (1):44-51.

Santoso, U. 2018. Penggunaan daun katuk (Sauropus androgynus) sebagai suplemen pakan pada unggas. Pengaruhnya terhadap performa ayam. Jurnal Sains Peternakan Indonesia, 13(2):151-156.

Sawen D. 2011. Pengamatan ekologi padang rumput alam Kebar Papua dan uji produktivitas banondit (Biophytum petersianum Klotzsch) melalui pemberian nitrogen dan interval defoliasi. [Tesis]. Bogor: Fakultas Peternakan Institut Pertanian Bogor.

Sawen D. 2012. Potensi Tanaman Obat Banondit (Biophytum petersianum Klotzsch) sebagai sumber pakan hijauan di Lembah Kebar Papua Barat. Pastura. 2(1):34-36.

Suherman D. dan Herdiawan I. 2014. Tanaman legum pohon Desmodium rensonii sebagai tanaman pakan ternak bermutu. Pastura. 4(2):100-104.

Sukasini S., Bhargav I. M., Sakthi P. S., Kumar P. R. 2015. Retrospect of Ormocarpum sennoides (Wild) DC: A boon to phytomedicine. Global J. res.Med. plants \& Indigen. Med. 4(10): 203-208.

Thulin M. and Razafimandimbison S. G. 2016. Ormocarpopsis anosyana Thulin \& Razafim. (Fabaceae), a new species from southern Madagaskar and its phylogenetic position. Condollea. 7(12): 281-286.

Thulin M., Philipson P. B. and Lavin M. 2013. Peltiera (Fabaceae), the coming and going of an "extinct" genus in Madagascar. Adansenia, Ser. 3, 35(1): 61-71. 